\title{
Coverage Estimation for Advanced Terrestrial Television ATSC 3.0
}

\author{
Fernanda Marinho Magalhães \\ Arismar Cerqueira Sodré Junior
}

\section{CITE THIS ARTICLE}

Magalhães, Fernanda Marinho Magalhães and Sodré Junior, Arismar Cerqueira; 2019. Coverage Estimation for Advanced Terrestrial Television ATSC 3.0. SET INTERNATIONAL JOURNAL OF BROADCAST ENGINEERING. ISSN Print: 2446-9246 ISSN Online: $2446-9432$. doi: 10.18580/setijbe.2019.5. Web Link: http://dx.doi.org/10.18580/setijbe.2019.5 


\title{
Coverage Estimation for Advanced Terrestrial Television - ATSC 3.0
}

\author{
Fernanda Marinho Magalhães ${ }^{1} \&$ Arismar Cerqueira Sodré Junior ${ }^{2}$
}

\begin{abstract}
Summary - The ATSC 3.0 standard allows for the provision of new high data rate services, so it has been considered as a benchmark in television broadcasting technology worldwide. This paper presents a numerical study of coverage prediction using Progira software. Coverage is evaluated using ISDB-Tb and ATSC 3.0 digital terrestrial television standards in the cities of Santa Rita do Sapucaí-MG and São Paulo-SP.
\end{abstract}

Keywords - ATSC 3.0, ISDB-TB, Propagation, and TV

\section{INTRODUCTION}

The growing development of wireless technologies makes it necessary to ensure sufficient transmission capacity to provide various high-quality services. The improvement of multimedia content with the emergence of cutting-edge technologies such as $4 \mathrm{~K}$ UHDTV or the new HEVC video encoding standard is pushing the limits of network capacity.

In the case of Digital Terrestrial Television (DTTV), the importance of improving spectral efficiency is critical to maintaining it as an attractive and competitive platform against cable or wireless solutions. The launch of television broadcast spectrum for the fourth generation of mobile broadband (4G) services in the $700 \mathrm{MHz}$ band has limited the spectrum dedicated to terrestrial broadcasting. Therefore, TDT enhancement involves an improvement in spectral efficiency.

As such, recent digital television standards are focused on improving these two aspects of broadcasting, such as ATSC 3.0. This standard was developed by the Advanced Television Systems Committee and considers rates of $50 \mathrm{Mb} / \mathrm{s}$, in order to receive the best definition content available today and have great flexibility depending on the desired service.

Additionally new transmission techniques have been developed, in particular different multiplexing modes for digital television networks. Layered Division Multiplexing (LDM) allows the allocation of fixed and mobile services divided into energy. Channel Bonding enables the use of two independent RF channels for a single data stream. ATSC 3.0 provides for the use of $2 \times 2$ Multiple Input Multiple Output (MIMO) with cross-polarization antennas [1]. This paper reports simulations performed on Progira software, which runs on the ArcGis geoprocessing platform [2], to assess the coverage of the new ATSC 3.0 digital television system.

\section{ATSC 3.0}

ATSC 3.0 is the new Terrestrial Digital Television standard developed by the Advanced Television Systems Committee (ATSC). This standard is based on Orthogonal Frequency Division Multiplexing (OFDM) and the use of Low Density Parity Check (LDPC) for low density parity checking. The physical layer implemented is aimed at greater robustness, flexibility and efficiency than previous standards due to the use of non-uniform constellations, LDPC codes and LDM.

The main parameters of an ATSC 3.0 transmission mode are:

- Bandwidth 6 to $8 \mathrm{MHz}$;

- FFT 8,16 and $32 \mathrm{~K}$;

- Guard interval from $27.78 \mu \mathrm{sec}$ to $703.70 \mu \mathrm{sec}$ in twelve patterns;

- Scattered pilot frequency spacing: Normal or Dense are the values used;

- Scattered pilot time spacing - The values available are 2 or 4 ;

- Constellation size - The orders 4, 16, 64, 256, 1024 and 4096-QAM are defined;

- LDPC with 16200 or 64800 bit FEC internal code;

- LDPC code rate between 2/15 and 13/15;

- BCH: Bose,Ray-Chaudhuri and Hocquenghem FEC outer code used in the BICM module. ON y OFF are the options;

- Frame length of 100, 150, 200 or 250 ms.

- Typical LD injection level of $-4 \mathrm{~dB}$ [1].

ATSC 3.0 standardization features Order Two MIMO (MIMO 2x2) with cross-polarized technology. In other words, it is a technology in which two antennas are used, one vertically polarized and one horizontally polarized, both on the transmitter side and the receiver side. In addition, on the receiver side, two tuners are required to receive and decode the MIMO signal. In particular, this standard applies MIMO to make use of spatial diversity to minimize the effects of small and large scale fading, shading and path loss. Systems with spatial diversity can be splitted into four classes: SISO (Single Input Single Output); SIMO (Single Input Multiple Output); MISO (Multiple Input Single Output); MIMO (Multiply Input Multiply Output) [3].

ISDB-Tb was developed from the evolution of the Japanese ISDB-T (Integrated Services Digital Broadcasting Terrestrial) standard and was officially launched in Brazil in 2007. This 
system is flexible and designed to deliver high quality audio and high definition image for fixed and mobile reception. The transmission of digital terrestrial television service is divided into source coding, channel coding, OFDM modulation and broadcasting [4]. Table I presents a comparison between ISDB-Tb and ATSC 3.0 systems.

TABLE I

COMPARISON OVERVIEW BETWEEN ISDB-Tb E ATSC 3.0 [1] [4].

\begin{tabular}{|c|c|c|}
\hline \multirow{2}{*}{ PARAMETERS } & \multicolumn{2}{|r|}{ SYSTEM } \\
\hline & ISDB-Tb & ATSC 3.0 \\
\hline Transport Protocol & TS & IP \\
\hline Guard Range & $\begin{array}{c}1 / 4 ; 1 / 8 ; 1 / 16 \mathrm{e} \\
1 / 32\end{array}$ & $\begin{array}{c}3 / 512,3 / 256,1 / 64,3 / 128,1 / 32 \\
3 / 64,1 / 16,19 / 256,3 / 32,57.512 \\
3 / 16,1 / 8,19 / 128,1 / 4\end{array}$ \\
\hline $\begin{array}{c}\text { Video } \\
\text { Compression }\end{array}$ & Н.264 & Н.265 \\
\hline $\begin{array}{c}\text { Audio } \\
\text { Compression }\end{array}$ & $\begin{array}{c}\text { MPEG-4 HE } \\
\text { AAC }\end{array}$ & MPEG-H \\
\hline Diversity & SISO & SISO;MISO;MIMO \\
\hline Band & $6 ; 7 ; 8 \mathrm{MHz}$ & $6 ; 7 ; 8 \mathrm{MHz}$ \\
\hline Internal decoder & $\begin{array}{c}\mathrm{CC}: 1 / 2 ; 2 / 3 \\
3 / 4 ; 4 / 5 ; 5 / 6 \\
7 / 8\end{array}$ & $\begin{array}{c}\text { LDPC: } \\
\{2,3,4,5,6,7,8,9,10,11,12,13\} / 15\end{array}$ \\
\hline Modulation & $\begin{array}{c}\text { DQPSK, QPSK, } \\
\text { 16-QAM, 64- } \\
\text { QAM }\end{array}$ & $\begin{array}{c}\text { QPSK, 2D-16NUC, 2D- 64NUC, } \\
\text { 2D-256NUC, 1D- 1024NUC, 1D- } \\
4096 \mathrm{NUC}\end{array}$ \\
\hline Frame size & 1632 bits & 16200 e 64800 bits \\
\hline External Decoder & $\mathrm{RS}(204,188,8)$ & BCH, CRC OU NENHUM \\
\hline $\begin{array}{c}\text { Rotated } \\
\text { Constellation }\end{array}$ & '--- & não \\
\hline IFFT Size & $2 \mathrm{~K} ; 4 \mathrm{~K} ; 8 \mathrm{~K}$ & $8 \mathrm{~K} ; 16 \mathrm{~K} ; 32 \mathrm{~K}$ \\
\hline
\end{tabular}

\section{PROGIRA SOFTWARE}

Coverage prediction software should have a land and construction map to calculate the field strength of each pixel of the area of interest, taking into account diffraction, tropospheric dispersion, reflection, refraction, and land and construction entry loss.

In this study, the Progira coverage prediction software was used, which works on the ArcGis geoprocessing platform [2]. Fig. 1 reports the ISDB-T standard parameters, which were considered in the numerical simulations, including 64-QAM modulation, FEC 3/4, 10m reception antenna height and $10 \mathrm{dBd}$ reception antenna gain [5]. Fig. 2 shows the ATSC 3.0 system parameters, such as FFT of 32K, 4096-QAM modulation, $13 / 15$ code rate and $28 \mathrm{~ms}$ guard interval, which result in a rate of $55.25 \mathrm{Mb} / \mathrm{s}$.

Progira software provides the most important propagation models in the literature: CRC - Predict, ITUR P.1546-5, ITUR GE06, ITUR P.370-7, ITUR P.526-13, ITUR P.1812-3, Deygout- Assisi, Longley-Rice and Okumura-Hata. The propagation model used in the simulations was the CRCPredic, which implements calculation of the diffraction attenuation on the terrain and part of the loss caused by terrain reflections. The loss due to reflection is estimated using a clutter, which is a set of polygons with the region classification, such as degree of urbanization and vegetation. There is an attenuation value associated with each polygon class [6].

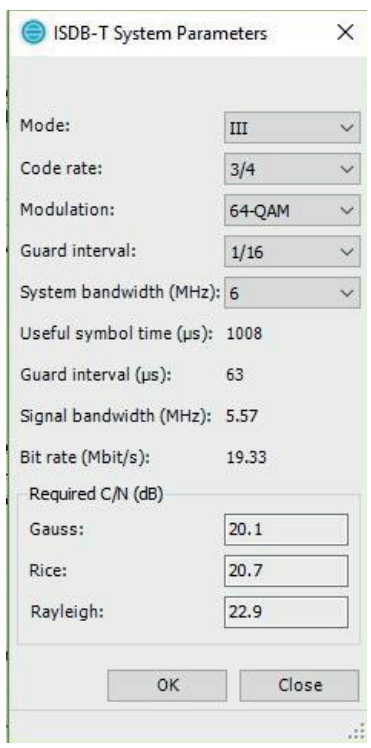

Fig. 1 - ISDB-TB Patterns used on simulation

The electric field intensity of television and retransmission stations using digital technology will be determined on the basis of Tables E $(50,90)$, which correspond to field strength values exceeded in $50 \%$ of locations for $90 \%$ of the time, at distances from $1 \mathrm{~km}$ to $1,000 \mathrm{~km}$ from the irradiation center of a dipole antenna powered by $1 \mathrm{~kW}$ of effective power [5]. The service area of a digital terrestrial television broadcast or retransmission station corresponds to the area bounded by the service contour, characterized by the values of electric field strength [5]. Finally, the software uses IBGE data to determine the population covered by the TV signal.

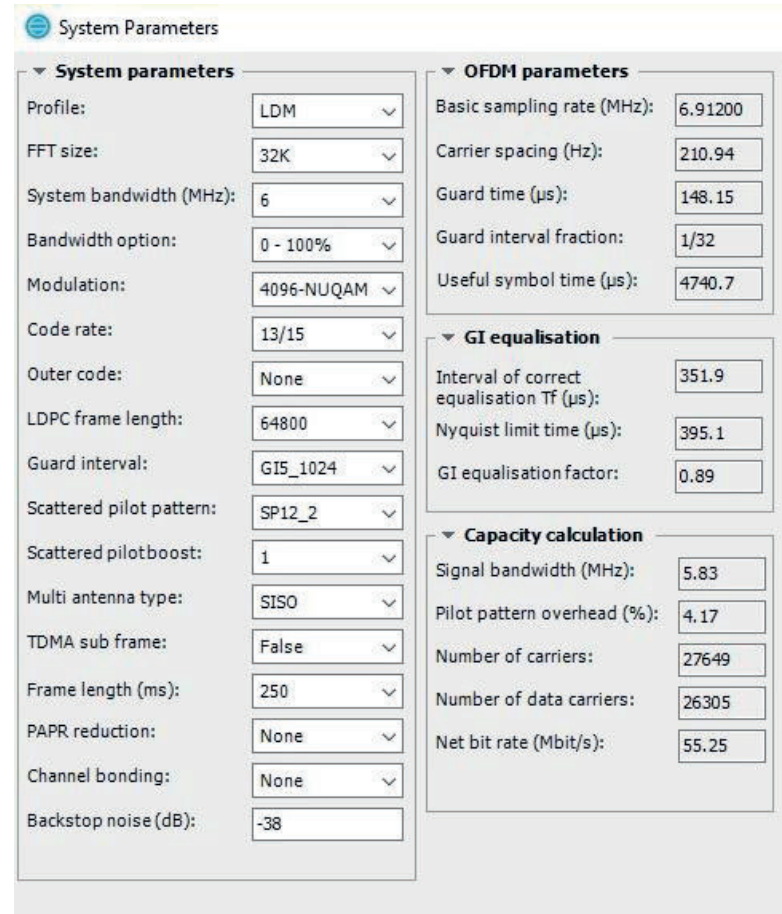

Fig. 2 - ATSC 3.0 Patterns used on simulation 


\section{RESULTS}

The cities Santa Rita do Sapucaí-MG and São Paulo-SP were chosen for the study of Digital Terrestrial Television using ISDB-T and ATSC 3.0 standards, under the propagation conditions shown in Fig. 3 and Fig. 4, respectively. The specifications of each of the city broadcasting sites are described in Tab. II.

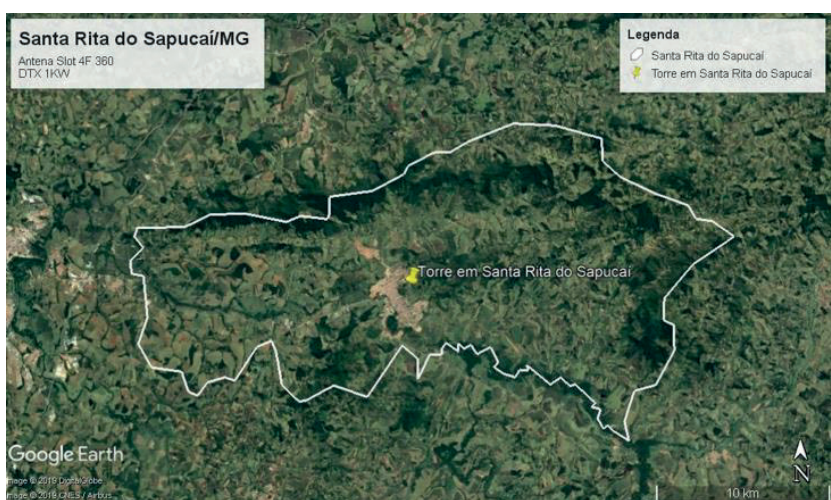

Fig. 3 - Map of Santa Rita do Sapucaí-MG, with the broadcast site identified with the yellow mark.

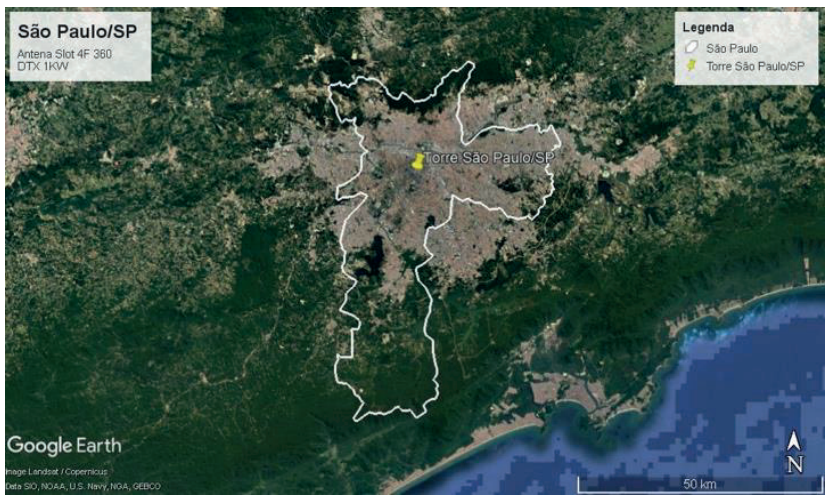

Fig. 4 - Map of São Paulo-SP, with the broadcast site identified with the yellow mark.

TABLE II

TECHNICAL SPECIFICATIONS OF SANTA RITA E SÃO PAULO SITES

\begin{tabular}{|c|c|c|c|}
\hline \multicolumn{2}{|c|}{ ESPEC IFIC AÇ Õ ES } & Sta Rita do Sapucaí/MG & São Paulo/SP \\
\hline \multicolumn{2}{|c|}{ CANAL (UHF) } & 20 & 20 \\
\hline \multicolumn{2}{|c|}{$\begin{array}{l}\text { PO TÊNCIA TRANSMISSOR } \\
\text { DIGITAL }\end{array}$} & $1 \mathrm{KW}$ & $1 \mathrm{KW}$ \\
\hline \multirow{2}{*}{$\begin{array}{l}\text { COORDENADA } \\
\text { S DE } \\
\text { INSTALAC } \tilde{O} O\end{array}$} & Latitude & $22^{\circ} 14^{\prime} 36,74^{\prime \prime} \mathrm{S}$ & $23^{\circ} 33^{\prime} 43,43^{\prime \prime} \mathrm{S}$ \\
\hline & Longitude & $45^{\circ} 41^{\prime} 53,26^{\prime \prime} \mathrm{W}$ & $46^{\circ} 39^{\prime} 13,94^{\prime \prime} \mathrm{W}$ \\
\hline \multirow{6}{*}{$\begin{array}{l}\text { SIS TEMA } \\
\text { IRRADIANTE }\end{array}$} & Tipo & Slot 4 Fendas omni & Slot 4 Fendas omni \\
\hline & Polarização & Horizontal & Horizontal \\
\hline & Ganho & $7,6 \mathrm{dBd}$ & $7,6 \mathrm{dBd}$ \\
\hline & $\mathrm{HCI}$ & $32 \mathrm{~m}$ & $155 \mathrm{~m}$ \\
\hline & Azimute & $260^{\circ} \mathrm{NV}$ & $140^{\circ} \mathrm{NV}$ \\
\hline & Tilt & $0^{\circ}$ & $0^{\circ}$ \\
\hline \multirow{3}{*}{$\begin{array}{c}\text { LINHA DE } \\
\text { TRANSMISS ÃO }\end{array}$} & Tipo & $15 / 8 "$ & $15 / 8 "$ \\
\hline & Comprimento & $37 \mathrm{~m}$ & $80 \mathrm{~m}$ \\
\hline & Atenuação & $0,5701 \mathrm{~dB} / 37 \mathrm{~m}$ & $1,2328 \mathrm{~dB} / 80 \mathrm{~m}$ \\
\hline \multirow{2}{*}{ ERP (W) } & Horizontal & 4497,8 & \\
\hline & Vertical & --- & \\
\hline
\end{tabular}

The ISDB-TB standard data used in the simulations are presented in Table III to provide a rate of $19.33 \mathrm{Mb} / \mathrm{s}$ for a signal-noise ratio (SNR) of $20.1 \mathrm{~dB}$ [7], as shown in the coverage map of Figure 5, considering fixed reception $(10 / 0 \mathrm{dBd})$ and a $51 \mathrm{dBuV} / \mathrm{m}$ field. In this way, a population of about 167,566 inhabitants of the South of Minas Gerais, distributed in cities near Santa Rita Station, can be served, as reported in Table V. The results for the city of São Paulo are presented in Figure 6 and Table VI, which identifies a population served of $13,825,116$ inhabitants.

TABLE III

PARAMETERS OF THE TRANSMISSION MODE USED ISDB-T FIXED SERVICE

\begin{tabular}{|c|c|}
\hline BAND & $6 \mathrm{MHz}$ \\
\hline FEC & $3 / 4$ \\
\hline MODULATION & $64-\mathrm{QAM}$ \\
\hline GUARD INTERVAL & $1 / 16$ \\
\hline
\end{tabular}

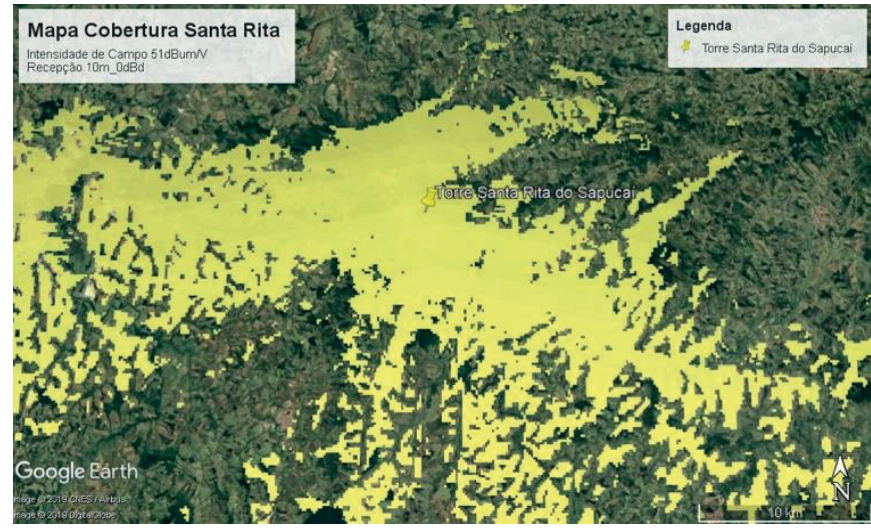

Fig. 5- Coverage Map on Santa Rita do Sapucaí-MG site considering fixed reception $(10 \mathrm{~m} / 0 \mathrm{dBd})$ and field of $51 \mathrm{dBuV} / \mathrm{m}$.

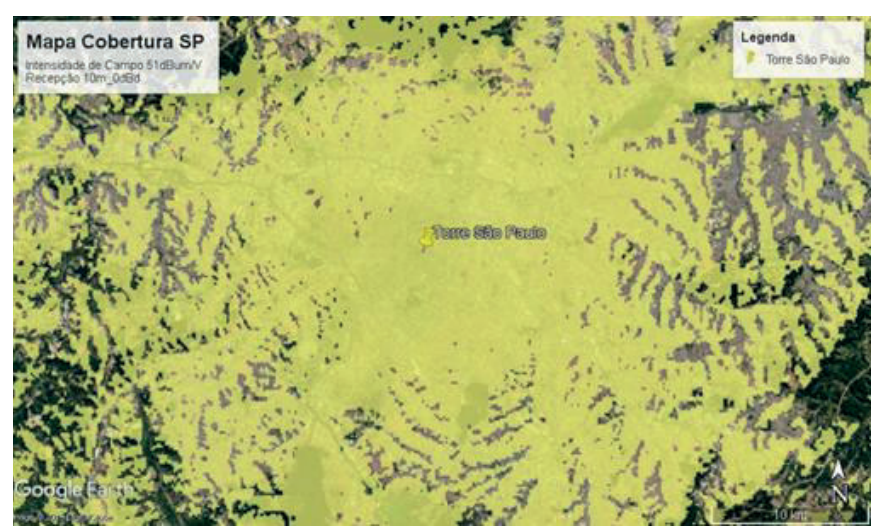

Fig. 6 - Coverage Map on São Paulo/SP site considering fixed reception (10m (0dBd) and field of $51 \mathrm{dBuV} / \mathrm{m}$.

ATSC 3.0 coverage prediction simulations were also performed, according to the parameters of Table IV, using SISO. 
PARAMETERS OF THE TRANSMISSION MODE USED IN ATSC FIXED SERVICE 3.0

\begin{tabular}{|c|c|c|c|}
\hline BW & $6 \mathrm{MHz}$ & QAM & 1024 \\
\hline FFT & $32 \mathrm{~K}$ & LDPC & 64800 bits \\
\hline GI & $148.148 \mu \mathrm{s}$ & LDPC (Code Rate) & $13 / 15$ \\
\hline DX & Normal & BCH & ON \\
\hline DY & 2 & Frame & $200 \mathrm{~ms}$ \\
\hline
\end{tabular}

Thus, a rate of $45.64 \mathrm{Mb} / \mathrm{s}$ was obtained for $\mathrm{SNR}=30.18$ dB. Figure 7 and Table VII report the results for ATSC 3.0 with SISO, where a large coverage area with population served of $15,086,762$ in habitants is observed.

TABLE V

POPULATION COVERED BY ISDB-Tb STANDARD IN SOUTH MINAS GERAIS

\begin{tabular}{|l|c|c|c|}
\hline \multicolumn{1}{|c|}{ City } & Total pop & Served Pop & Served Pop \% \\
\hline Santa Rita do Sapucaí & 37.436 & 35.497 & 94,8 \\
\hline Pouso Alegre & 129.581 & 108.784 & 84 \\
\hline São José do Alegre & 3.989 & 2.959 & 74,2 \\
\hline Brasópolis & 14.517 & 4.041 & 27,8 \\
\hline Piranguinho & 7.976 & 2.095 & 26,3 \\
\hline Paraisópolis & 19.262 & 3.472 & 18 \\
\hline Conceição dos Ouros & 10.340 & 1.800 & 17,4 \\
\hline Cachoeira de Minas & 10.970 & 1.153 & 10,5 \\
\hline Senador José Bento & 1.865 & 135 & 7,2 \\
\hline Tocos do Moji & 3.948 & 251 & 6,4 \\
\hline Itajubá & 90.019 & 4.713 & 5,2 \\
\hline Wenceslau Braz & 2.547 & 130 & 5,1 \\
\hline Gonçalves & 4.194 & 176 & 4,2 \\
\hline Piranguçu & 5.179 & 203 & 3,9 \\
\hline São Sebastião da Bela Vista & 4.912 & 157 & 3,2 \\
\hline Borda da Mata & 17.020 & 514 & 3 \\
\hline Pedralva & 11.402 & 342 & 3 \\
\hline Córrego Do Bom Jesus & 3.725 & 101 & 2,7 \\
\hline Delfim Moreira & 7.943 & 172 & 2,2 \\
\hline Estiva & 10.826 & 215 & 2 \\
\hline Bom Repouso & 10.427 & 173 & 1,7 \\
\hline Maria Da Fé & 14.156 & 151 & 1,1 \\
\hline Careaçu & 6.254 & 57 & 0,9 \\
\hline Congonhal & 10.361 & 85 & 0,8 \\
\hline Consolação & 1.719 & 6 & 0,3 \\
\hline Inconfidentes & 6.905 & 18 & 0,3 \\
\hline Natércia & 4.611 & 14 & 0,3 \\
\hline Heliodora & 6.094 & 10 & 0,2 \\
\hline Ipuiúna & 9.444 & 19 & 0,2 \\
\hline Ouro Fino & 31.370 & 61 & 0,2 \\
\hline Camanducaia & 20.839 & 25 & 0,1 \\
\hline Cristina & 10.146 & 14 & 0,1 \\
\hline Santa Rita De Caldas & 8.975 & 10 & 0,1 \\
\hline Sapucaí-Mirim & 6.227 & 7 & 0,1 \\
\hline Silvianópolis & 5.985 & 6 & 0,1 \\
\hline TOTAL POPULATION COVERAGE & 167.566 & --- \\
\hline
\end{tabular}

TABLE VI
SÃO PAULO SERVED POPULATION WITH THE ISDB-TB STANDARD.

\begin{tabular}{|l|c|c|c|}
\hline \multicolumn{1}{|c|}{ City } & Total pop & Served Pop & Served Pop \% \\
\hline São Paulo & 11.206 .957 & 8.855 .507 & 79 \\
\hline Guarulhos & 1.214 .007 & 900.934 & 74,2 \\
\hline São Bernardo Do Campo & 761.735 & 613.777 & 80,6 \\
\hline Santo André & 673.645 & 555.901 & 82,5 \\
\hline Osasco & 665.402 & 480.177 & 72,2 \\
\hline Diadema & 385.513 & 291.872 & 75,7 \\
\hline Mauá & 415.103 & 275.618 & 66,4 \\
\hline Carapicuíba & 369.020 & 247.955 & 67,2 \\
\hline Taboão Da Serra & 244.149 & 221.159 & 90,6 \\
\hline Embu & 239.994 & 193.005 & 80,4 \\
\hline Itaquaquecetuba & 321.384 & 176.120 & 54,8 \\
\hline Barueri & 240.595 & 163.416 & 67,9 \\
\hline São Caetano do Sul & 148.474 & 137.599 & 92,7 \\
\hline Mogi das Cruzes & 386.517 & 119.933 & 31 \\
\hline Cotia & 200.042 & 109.731 & 54,9 \\
\hline Itapecerica da Serra & 149.039 & 83.229 & 55,8 \\
\hline Ferraz De Vasconcelos & 168.016 & 73.524 & 43,8 \\
\hline Suzano & 261.487 & 64.019 & 24,5 \\
\hline Itapevi & 200.626 & 56.262 & 28 \\
\hline Jandira & 108.283 & 50.623 & 46,8 \\
\hline Arujá & 74.669 & 35.703 & 47,8 \\
\hline Ribeirão Pires & 112.752 & 26.677 & 23,7 \\
\hline Embu-Guaçu & 62.446 & 26.015 & 41,7 \\
\hline Santana De Parnaíba & 108.747 & 25.084 & 23,1 \\
\hline Poá & 105.779 & 22.045 & 20,8 \\
\hline Vargem Grande Paulista & 42.806 & 8.622 & 20,1 \\
\hline Rio Grande Da Serra & 43.776 & 3.148 & 7,2 \\
\hline São Roque & 78.642 & 2.514 & 3,2 \\
\hline Mairiporã & 80.615 & 1.634 & 2 \\
\hline Caieiras & 86.352 & 1.534 & 1,8 \\
\hline Pirapora Do Bom Jesus & 15.691 & 883 & 5,6 \\
\hline Cajamar & 64.044 & 505 & 0,8 \\
\hline Nazaré Paulista & 16.390 & 122 & 0,7 \\
\hline Franco Da Rocha & 123.467 & 102 & 0,1 \\
\hline São Lourenço Da Serra & 13.885 & 92 & 0,7 \\
\hline Araçariguama & 16.920 & 40 & 0,2 \\
\hline Cabreúva & 41.518 & 35 & 0,1 \\
\hline TOTAL POPULATION COVERAGE & 13.825 .116 & --- \\
\hline & & & \\
\hline & & & \\
\hline
\end{tabular}

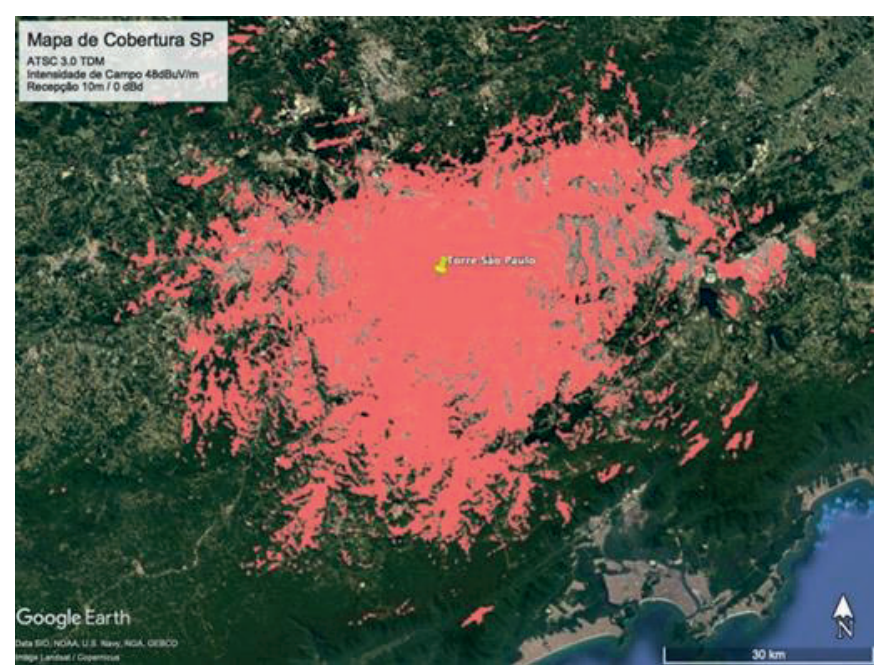


Fig. 7 - Coverage Map on São Paulo/SP site using ATSC 3.0 standard, TDM and SISO antenna.

TABLE VII

SÃO PAULO / SP SERVED POPULATION FOR ATSC 3.0

\begin{tabular}{|c|c|c|c|}
\hline City & Total pop & Served Pop & Served Pop \% \\
\hline São Paulo & 11.206 .957 & 9.514 .798 & 84,9 \\
\hline Guarulhos & 1.214 .007 & 997.592 & 82,2 \\
\hline São Bernardo Do Campo & 761.735 & 656.091 & 86,1 \\
\hline Santo André & 673.645 & 597.024 & 88,6 \\
\hline Osasco & 665.402 & 530.961 & 79,8 \\
\hline Diadema & 385.513 & 325.191 & 84,4 \\
\hline Mauá & 415.103 & 304.855 & 73,4 \\
\hline Carapicuíba & 369.020 & 277.651 & 75,2 \\
\hline Taboão Da Serra & 244.149 & 231.842 & 95 \\
\hline Embu & 239.994 & 207.728 & 86,6 \\
\hline Itaquaquecetuba & 321.384 & 203.201 & 63,2 \\
\hline Barueri & 240.595 & 184.884 & 76,8 \\
\hline Mogi Das Cruzes & 386.517 & 166.551 & 43,1 \\
\hline São Caetano Do Sul & 148.474 & 142.883 & 96,2 \\
\hline Cotia & 200.042 & 123.987 & 62 \\
\hline Itapecerica Da Serra & 149.039 & 98.126 & 65,8 \\
\hline Ferraz De Vasconcelos & 168.016 & 90.152 & 53,7 \\
\hline Suzano & 261.487 & 89.446 & 34,2 \\
\hline Itapevi & 200.626 & 79.844 & 39,8 \\
\hline Jandira & 108.283 & 63.517 & 58,7 \\
\hline Arujá & 74.669 & 41.997 & 56,2 \\
\hline Ribeirão Pires & 112.752 & 38.256 & 33,9 \\
\hline Embu-Guaçu & 62.446 & 31.525 & 50,5 \\
\hline Santana De Parnaíba & 108.747 & 30.595 & 28,1 \\
\hline Poá & 105.779 & 28.954 & 27,4 \\
\hline Vargem Grande Paulista & 42.806 & 10.792 & 25,2 \\
\hline Rio Grande Da Serra & 43.776 & 7.695 & 17,6 \\
\hline São Roque & 78.642 & 3.301 & 4,2 \\
\hline Mairiporã & 80.615 & 2.348 & 2,9 \\
\hline Caieiras & 86.352 & 2.048 & 2,4 \\
\hline Pirapora Do Bom Jesus & 15.691 & 1.215 & 7,7 \\
\hline Cajamar & 64.044 & 713 & 1,1 \\
\hline Jundiaí & 368.998 & 241 & 0,1 \\
\hline Franco Da Rocha & 123.467 & 219 & 0,2 \\
\hline Nazaré Paulista & 16.390 & 164 & 1 \\
\hline São Lourenço Da Serra & 13.885 & 158 & 1,1 \\
\hline Araçariguama & 16.920 & 55 & 0,3 \\
\hline Biritiba-Mirim & 28.541 & 55 & 0,2 \\
\hline Cabreúva & 41.518 & 49 & 0,1 \\
\hline Salesópolis & 15.580 & 27 & 0,2 \\
\hline Campos Do Jordão & 47.289 & 25 & 0,1 \\
\hline Igaratá & 8.799 & 6 & 0,1 \\
\hline \multicolumn{2}{|c|}{ TOTAL POPULATION COVERAGE } & 15.086 .762 & --- \\
\hline
\end{tabular}

After numerous simulations, it was found that the coverage map and population served for MIMO mode was identical to SISO mode. We contacted Progira and they confirmed to us that the MIMO function is available in the software but is still in the implementation phase.

\section{CONCLUSIONS}

This work reported numerical coverage prediction simulations performed with the Progira software in the context of the cities of Santa Rita do Sapucaí-MG and São Paulo-SP. The simulations showed that the ATSC 3.0 system, compared to the ISDB-T, can deliver twice the usable rate for a $6 \mathrm{MHz}$ band, as well as greater coverage for both the city of Santa Rita do Sapucaí and São Paulo. Specifically, the ISDB-T standard obtained a rate of $19.33 \mathrm{Mb} / \mathrm{s}$ for $\mathrm{SNR}=20.1 \mathrm{~dB}$, while for the ATSC 3.0 standard a rate of $45.64 \mathrm{Mb} / \mathrm{s}$ for $\mathrm{SNR}=30.18 \mathrm{~dB}$.

For the ISDB-T standard, a population of about 167,566 inhabitants of Southern Minas Gerais, distributed in cities near Santa Rita do Sapucaí-MG station and 13.825,116 inhabitants distributed in cities near São Paulo-SP Station, can be served. For the ATSC 3.0 standard, in addition to the useful rate gain, a significant coverage gain was observed in cities near the São Paulo-SP Station that resulted in a population of $15.086,762$ inhabitants.

\section{REFERENCES}

[1] Advanced Television Systems Committee. "ATSC Standard: Physical Layer Protocol (A/322). Doc. A/322:2106." Washington, D.C, USA, September 2016

[2] ARCGIS. Online. Disponível em https://www.esri.com/enus/arcgis/about-arcgis/overview, acesso em 28 de abril de 2019.

[3] G. Lorenzo Cifuentes "Coverage estimation for the next-generation digital terrestrial television standard atsc 3.0: 1dm, channel bonding and mimo", Universidade Politécnica de Valência.2016. unplushed.

[4] P. G. Esperante, C. Akamine, G. Bedicks Jr "Comparison of Terrestrial DTV Systems: isdb-tb and dvb-t2 in $6 \mathrm{mhz",} \mathrm{IEEE} \mathrm{latin} \mathrm{america}$ transactions, volume 14, páginas 45 à 56, 2016.

[5] Ministério das Comunicações Gabinete do Ministro "Portaria n ${ }^{\circ}$ 925, de 22 de agosto de 2014", DOU de 27/08/2014 (nº 164, Seção 1, pág. 93).

[6] F. S. Silva, L. J. Matos, F. A. C. Peres, G. L Siqueira, "Coverage prediction models fitted to the signal measurements of digital TV in Brazilian cities", 2013 SBMO/IEEE MTT-S International Microwave \& Optoelectronics Conference (IMOC), 2013.

[7] ARIB STD-B31, Versão 1.6, traduzida para o inglês, 2005. Online. Disponível em: https://www.arib.or.jp/english/index.html, acesso em 28 de fevereiro de 2019.

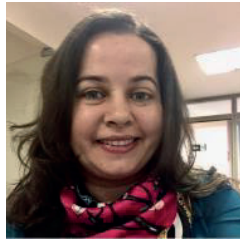

Fernanda Marinho Magalhães is attending postgraduate course in Network and Telecommunications Engineering from INATEL. Graduated in Electrical Engineering from Nove de Julho University, graduated in Economics from UESC and Electronic Technician from CEFET / BA. Has been working in the area of television broadcasting for over 15 years, closely following the birth and implementation of the digital terrestrial TV standard in Brazil. Her topics of interest are broadband multimedia communications, digital broadcasting and communication systems engineering. 
the Federal University of Bahia (2001), a Master's degree in Electrical Engineering from the State University of Campinas (2002), a Ph.D. in Telecommunications Engineering from Scuola Superiore Sant' Anna Italy and University of Bath - England (2006) and Post-Doctorate in Electrical Engineering from UNICAMP (2009). Currently works as Assistant Professor IV of Inatel. Arismar has 10 patents, 19 products transferred to industry and 223 articles published in international and national journals and congresses. 